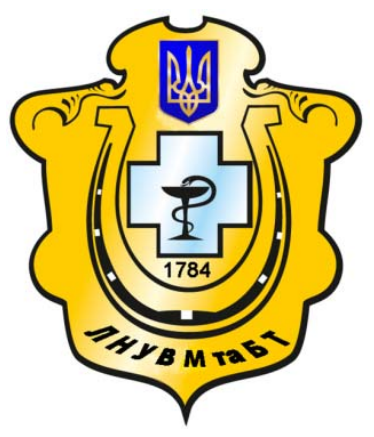

Науковий вісник Львівського національного університету ветеринарної медицини та біотехнологій імені С.3. Гжицького

Scientific Messenger of Lviv National University of Veterinary Medicine and Biotechnologies named after S.Z. Gzhytskyj

doi:10.15421/nvlvet7121

ISSN 2413-5550 print

ISSN 2518-1327 online

$\underline{\text { http://nvlvet.com.ua/ }}$

УДК 619:615:619:617:636.2

\title{
Ефективність «Мазі для ран» у комплексній терапії при лікуванні рваних ран дійок вимені корів
}

\author{
P.М. Сачук \\ sachuk.08@mail.ru
}

Дослідна станиія епізоотології ІВМ НААН,

вул. Князя Володимира, 16/18, 33024, Рівне, Україна

\begin{abstract}
При вивченні патологій молочної залози в корів встановлено, щео рани вимені становлять 1,2\% у загальній структурі захворювань. Пік травматизму молочної залози у корів припадає на літо (пасовищно-вигульний період) - 77,3\%, щьо пов'язано із недотриманням санітарно-гігієнічних вимог при вигоні та випасанні худоби. При апробації нових схем лікування ран сосків вимені застосовано «Мазь для ран» на основі ефірних олій сосни сибірської, евкаліпту, гвоздики, кедра, чайного дерева та масляного розчину хлорофіліпту. При застосуванні препарату при рваних ранах дійок вимені у корів встановлено високу ефективність і скорочення термінів лікування у порівнянні з традиційним засобом "Мазь окситетрачиклінова 5\%", яка містить окситетрациклін - напівсинтетичний антибіотик тетрациклінового ряду. Комплексна терапія, що включає застосування препарату для зовнішнього використання «Мазі для ран» та підшкірні ін'єкиї нестероїдного протизапального засобу "Целексиб», разом із закриттям ранових дефектів швами з полігліколіду, сприяє покращенню клінічного стану корів. Відзначено підвищення вмісту гемоглобіну на 6,1\%, кількості еритрочитів - 11,4\% $і$ зниження лейкоџитів - 9\% у крові, порівняно із традиційним методом лікування («Мазь окситетрачиклінова 5\%» та нестероїдний препарат «Кефен»). Місиеве використання фітопрепарату «Мазь для ран» та підикірних ін'єкиій «Целексибу» сприяє прискоренню затухання запальної реакції у 1,3 рази, зменшення набряку тканин - 1,2 рази та активізації регенеративних процесів, що дозволяє скоротити терміни лікування на 5 - 6 діб у порівнянні з контрольними тваринами.

Ключові слова: мазь, рана, запалення, набряк, рубещь, ефірне масло, масляний розчин, «Мазь для ран», «Мазь окситетрациклінова 5\%», «Целексиб», «Кефен».
\end{abstract}

\section{Эффективность «Мази для ран» в комплексной терапии при лечении рваных ран сосков вымени коров}

\author{
P.Н. Сачук \\ sachuk.08@mail.ru
}

Исследовательская станция эпизоотологии ИВМ НААН, ул. Князя Владимира, 16/18, 33024, Ровно, Украина

\begin{abstract}
При изучении патологий молочной железы у коров установлено, что раны вымени составляют 1,2\% в общей структуре заболеваний. Пик травматизма молочной железы у коров приходится на лето (пастбищно-выгульный период) - 77,3\%, что связано с несоблюдением санитарно-гигиенических требований при выгоне и выпасе скота. При апробации новых схем лечения ран сосков вымени была применена «Мазь для ран» на основе эфирных масел сосны сибирской, эвкалипта, гвоздики, кедра, чайного дерева и масляного раствора хлорофиллипта. В проиессе применения препарата при рваных ранах сосков вымени у коров установлена высокая эффективность и сокращение сроков лечения по сравнению с традиционным средством «Мазь окситетрачиклиновая 5\%», содержащая окситетраииклин - полусинтетический антибиотик тетрациклинового ряда. Комплексная терапия, включающая применение препарата для наружного использования «Мазь для ран» и подкожные инъекции НПВП «Целексиб», вместе с закрытием раневых дефектов швами из полигликолида, способствует улучшению клинического состояния коров. Отмечено повышение содержания гемоглобина на 6,1\%, количества эритроцитов -
\end{abstract}

Citation:

Sachuk, R.N. (2016). Efficiency of «Oinment for wounds» in the complex therapy of avulsive wounds of cows' udder teats. Scientific Messenger LNUVMBT named after S.Z. Gzhytskyj, 18, 3(71), 91-94. 
11,4\%, снижение лейкочитов - 9\% в крови по сравнению с традиционным методом лечения («Мазь окситетраииклиновая 5\%» и нестероидный препарат «Кефен»). Местное применение фитопрепарата «Мазь для ран» и подкожных инъекций «Целексиба» способствует ускорению затухания воспалительной реакции в 1,3 раза, уменьшению отека тканей - в 1,2 раза и активизации регенеративных прочессов, что позволяет сократить сроки лечения на 5 - 6 суток по сравнению с контрольными животнылми.

Ключевые слова: мазь, рана, воспаление, отек, рубец, эфирное масло, масляный раствор, «Мазь для ран», «Мазь окситетрациклиновая 5\%», «Целексиб», «Кефен».

\title{
Efficiency of «Oinment for wounds» in the complex therapy of avulsive wounds of cows' udder teats
}

\author{
R.N. Sachuk \\ sachuk.08@mail.ru \\ Research Epizootology Station IVM NAAS, \\ Knyaz Vladimir Str., 16/18, 33024, Rivne, Ukraine
}

\begin{abstract}
In the study of cows' mammary glands pathologies it was determined that the udder wounds constitute $1.2 \%$ in the overall structure of diseases. The peak of traumatism on cows' breast wounds falls on summer (pasture-range period) - 77.3\%, resulting from offences of sanitary requirements for cattle pasture and grazing. While testing new treatment regimens it was set the high efficiency of «Ointments for wounds» based on essential oils of Siberian Cedar, Eucalyptus, Clove, Cedar, Tea Tree and chlorophyllipt oil solution for treatment of avulsive wounds of cows' udder teats. It has been proven the reducing of time for treatment compared with traditional drugs "Oxytetracycline Ointment 5\%》 containing oxytetracycline - a semisynthetic antibiotic of a tetracycline series. Complex therapy, including application of preparation for external use "Ointment for wounds» and hypodermic injection of NSAID "Celecoxib», together with the wound defects closing by sutures with polyglycolide, promotes rapid correction of the clinical condition of cows. It was observed upregulating of hemoglobin by $6.1 \%$, the number of erythrocytes $-11.4 \%$, leukocytes $-9 \%$ in the blood, compared with the traditional method of treatment ("Oxytetracycline Ointment 5\%» and nonsteroidal drug "Kefen»). Local application of phytopreparation «Ointments for wounds》 and hypodermic injection of NSAID «Celecoxib» promotes acceleration of inflammatory reactions cancellation in 1,3 times, reduce udder edema - 1.2 times and enhance regenerative processes, thereby reducing treatment time $5-6$ days compared to control animals.
\end{abstract}

Key words: ointment, wound, inflammation, swelling, cicatricial tissue, essential oil, oil solution, "Ointment for wounds», "Oxytetracycline Ointment 5\%», «Celecoxib», «Kefen».

\section{Вступ}

В структурі патологій вимені корів механічні травми дійок займають незначне місце, однак вони завдають значних економічних збитків через тривале лікування із значною кількістю ускладнень і часто летальними випадками.

Відкриті травми соска часті при випасі тварин в лісистій місцевості, при утриманні в загонах із колючого дроту. Їх появі сприяє порушення технології утримання: невідповідність розміру стійл, прив'язу, перегородок, підлоги (Kolchina et al., 2010).

Не дивлячись на істотні успіхи ветеринарної медицини, проблема раціонального та обгрунтованого лікування ран молочної залози в корів, продовжує залишатися в центрі уваги практикуючих лікарів. У цьому напряму, закономірний інтерес викликає використання фітопрепаратів на основі ефірних олій сосни сибірської, евкаліпту, гвоздики, кедра, чайного дерева та масляного розчину хлорофіліпту, що об'єднані у зручній формі мазі та ін'єкції нестероїдних протизапальних засобів пролонгованої дії, які б не виділялися 3 молоком (Kosenko and Malik, 2001; Vaschenko, 2006).

Метою роботи було вивчення лікувальних властивостей препарату для зовнішнього використання «Мазь для ран», як складової комплексної терапії при рваних ранах дійок вимені у корів.

\section{Матеріал і методи дослідження}

Для лікування рваних ран дійок вимені у корів ДС епізоотології спільно 3 ТзОВ «ДЕВІЕ» розроблено препарат для зовнішнього використання «Мазь дляран», до складу якого входять ефірні олії сосни сибірської, евкаліпту, гвоздики, кедра, чайного дерева та масляний розчин хлорофіліпту.

Ефективність «Мазі для ран» при лікуванні рваних ран дійок вимені у корів вивчали на молочній фермі фермерського господарства «Мрія» Рівненського району Рівненської області на лактуючих коровах чорно-рябої породи віком $2-8$ років. Для цього відібрали 17 корів, яких розділили на дві групи. Тваринам обох груп проводили анестезію препаратом «Седазин» у дозі 0,025 мл на 10 кг маси тіла внутрішньовенно та блокаду нервів вимені $0,5 \%$ розчином новокаїну за I.I. Магдою у дозі 15 - 20 мл. Після санації на рани молочної залози корів накладали переривчасті петлевидні шви з полігліколіду (Kolchina et al., 2010).

Коровам 1-ї групи (дослідної, $\mathrm{n}=8$ ) після санації та хірургічної обробки ранової поверхні дійки обробляли препаратом «Мазь для ран». Для зняття постопераційного больового синдрому використовували нестероїдний протизапальний засіб «Целексиб», який вводили підшкірно у дозі 1 мл на 50 кг маси тіла, дворазово 3 інтервалом 48 годин. Тваринам 2-ї групи (контрольної, $\mathrm{n}=9$ ) зовнішньо використовували препарат «Мазь окситетрациклінова 5\%» та внутрішньом'язево, один раз на добу протягом 3 діб, вводили 
нестероїдний протизапальний засіб «Кефен», з розрахунку 3 мл препарату на 100 кг маси тіла.

При застосуванні «Седазину», «Целексибу» і «Кефену» молоко від корів під час та після лікування препаратами використовували без обмежень.

Після оперативного лікування у дійкову цистерну вводили самофіксуючий поліетиленовий молочний катетер із зовнішнім діаметром 4 мм. Пластикові катетери залишали на весь період загоєння ран і виймали на $10-12$ добу.

«Мазь для ран» та «Мазь окситетрациклінову 5\%» наносили на дійки вимені після закриття ранових дефектів швами, тонким шаром, злегка втираючи. Перед черговим доїнням, мазі змивали теплою водою, а вим'я витирали чистим рушником або одноразовою серветкою. Препарати на мазевій основі застосовували при щоденному діагностичному огляді тварин, симптоматично, від першого дня досліду до відсутності клінічних ознак ран дійок вимені. У схемі з «Маззю окситетрацикліновою 5\%» - впродовж 15 діб.

Морфологічні дослідження крові корів дослідної і контрольної групи проводили на 3, 6, 9 добу лікування. Кількість еритроцитів та лейкоцитів визначали в камері Горяєва, вміст гемоглобіну за допомогою гемометра. Дослідження крові також проводили на автоматичному гематологічному аналізаторі «РСЕ170». Статистичну обробку результатів проводили за загальноприйнятою біометричною методикою (Rokytskyy, 1973). Різницю між двома середніми величинами вважали статистично вірогідною при ${ }^{*}-\mathrm{p}<$ 0,$05 ;^{* *}-\mathrm{p}<0,01 ;^{* * *}-\mathrm{p}<0,001$.

\section{Результати та їх обговорення}

Аналізуючи отримані результати, слід відмітити, що серед патології молочної залози у корів домінува- ли мастити - 64,2\% від загальної кількості хворих тварин, 3 них субклінічні форми становили 28\%, а клінічні форми маститу - 12\%. Дерматити та папіломатоз дійок вимені за досліджуваний період виявили у 7,3\% тварин. Рани вимені становлять 1,2\% у загальній структурі захворювань. Встановлено, що пік травматизму молочної залози у корів припадає на літній (пасовищно-вигульний) період - 77,3\%, що пов'язано із недбалим ставленням до організації вигону та випасання худоби на стихійних, забруднених травмонебезпечними предметами пасовищах, а також конструктивні недоліки вигульних майданчиків.

Порівняння терапевтичної ефективності традиційної і запропонованої нами схем лікування (табл. 1) показало швидше покращення клінічних показників тварин дослідної групи. Перевага характеризувалася наступним: зменшенням набряку - на 21\% (у 1,2 рази), затуханням запальної реакції - на 25\% (у 1,3 рази), появою епітеліальної облямівки - на 18,8\%, формуванням рубця і його епітелізацією - на $37,7 \%$ та скороченням терміну лікування - на $34,4 \%$ або на 5 6 діб.

Так як у травмованих корів відзначали незначну еритропенію, лейкоцитоз і гемоглобінемію, терапевтичні процедури супроводжували відбором матеріалу для дослідження морфологічного складу крові тварин дослідної та контрольної груп. Після проведеного лікування досліджувані показники наблизилися до нормальних значень. За динамікою відновлення нормального фізіологічного стану організму, антибіотикотерапія поступається застосуванню фітопрепаратів (табл. 2).

В дослідній групі тварин не було відмічено ускладнень, а у контрольній групі зареєстровано два випадки маститу.

Таблиия 1

Ефективність різних методів лікування при ранах дійок вимені у корів, діб, $\mathbf{M} \pm \mathbf{m}, \mathbf{n}=17$

\begin{tabular}{|c|c|c|}
\hline \multirow{2}{*}{ Показник } & \multicolumn{2}{|c|}{ Група тварин } \\
\cline { 2 - 3 } & Дослідна & Контрольна \\
\hline Зменшення набряку & $3,50 \pm 0,29^{*}$ & $4,44 \pm 0,26$ \\
\hline Затухання запальної реакції & $5,00 \pm 0,29^{* *}$ & $6,67 \pm 0,25$ \\
\hline Поява епітеліальної облямівки & $6,50 \pm 0,22^{* * *}$ & $12,44 \pm 0,23$ \\
\hline Формування рубця, його епітелізація & $7,63 \pm 0,28^{* * *}$ & $15,44 \pm 0,31$ \\
\hline Термін лікування & $10,13 \pm 0,38^{* * *}$ & \\
\hline
\end{tabular}

Примітка: ${ }^{*}-\mathrm{p}<0,05 ;^{* *}-\mathrm{p}<0,01 ;{ }^{* * *}-\mathrm{p}<0,001$ у порівнянні 3 контрольною групою.

Таблицяя 2

Гематологічні показники корів при лікуванні ран дійок вимені, $\mathbf{M} \pm \mathbf{m}, \mathbf{n}=17$

\begin{tabular}{|c|c|c|c|c|}
\hline \multicolumn{2}{|c|}{ Час дослідження } & $\begin{array}{c}\text { Еритроцити } \\
(\text { Т/л) }\end{array}$ & $\begin{array}{c}\text { Лейкоцити } \\
(\text { Г/л) }\end{array}$ & $\begin{array}{c}\text { Гемоглобін } \\
(\text { г/л) }\end{array}$ \\
\hline \multicolumn{2}{|c|}{ До лікування } & $4,74 \pm 0,10$ & $10,67 \pm 0,11$ & $94,56 \pm 1,02$ \\
\hline \multirow{2}{*}{$\begin{array}{c}\text { Після лікування (діб) } \\
3\end{array}$} & Дослід & $5,45 \pm 0,06^{*}$ & $9,51 \pm 0,14^{* * *}$ & $100,50 \pm 1,18^{*}$ \\
\cline { 2 - 5 } & Контроль & $5,17 \pm 0,12$ & $9,89 \pm 0,05$ & $96,89 \pm 1,10$ \\
\hline \multirow{2}{*}{6} & Дослід & $5,66 \pm 0,10^{*}$ & $8,84 \pm 0,27^{*}$ & $105,31 \pm 1,16^{*}$ \\
\cline { 2 - 5 } & Контроль & $5,32 \pm 0,10$ & $9,57 \pm 0,22$ & $100,52 \pm 1,88$ \\
\hline \multirow{2}{*}{9} & Дослід & $6,16 \pm 0,11^{* * *}$ & $8,13 \pm 0,31^{*}$ & $110,25 \pm 1,01^{* * *}$ \\
\hline & Контроль & $5,53 \pm 0,08$ & $8,94 \pm 0,14$ & $104,00 \pm 1,03$ \\
\hline \multicolumn{2}{|c|}{} & $5-7,5$ & $6-12$ & $95-125$ \\
\hline
\end{tabular}




\section{Висновки}

1. Створений на основі комбінації ефірних олій сосни сибірської, евкаліпту, гвоздики, кедра, чайного дерева та масляного розчину хлорофіліпту препарат «Мазь для ран» у комплексній терапії з нестероїдним препаратом «Целексиб» показали високу лікувальну ефективність при рваних ранах дійок вимені у корів.

2. Встановлено, що тварини, котрим застосували «Мазь для ран» та «Целексиб» після закриття ранових дефектів швами, одужували в середньому за 10 діб. Комбінація препаратів сприяла прискоренню затухання запальної реакції, зменшенню набряку тканин, активізації регенеративних процесів та покращенню клінічного стану корів. Зокрема, підвищення вмісту гемоглобіну на $6,1 \%$, кількості еритроцитів - 11,4\%, зменшення лейкоцитів - на $9 \%$ у крові, порівняно із традиційним методом лікування («Мазь окситетрациклінова 5\%» та нестероїдний препарат «Кефен»).

Перспективи подальших досліджень. Подальші дослідження будуть спрямовані на апробацію препарату за інших видів патологій шкіри, зокрема, на вивчення ефективності «Мазі для ран» при гіперкератозі дійок вимені корів та завершення передреєстраційних клінічних випробувань.

\section{Бібліографічні посилання}

Kolchina, A.F., Elesin, A.V., Barkova, A.S., Kholina, T.G. (2010). Bolezny soskov molochnoy zhelezy korov kak factor ryska razvitiya mastita. [Diseases of teats of the udder in cows are the factors of risk of mastitis progress]. Monografiya. Monography. Ekaterenburg: UrSAA (in Russian).

Vaschenko, L.D. (2006). Phytoterapiya u veterenarniy medycyni. [Phytoterapy in veterinary medecine]. Navchalnyy posibnyk. - Educational text-book, Malyy Vystorop (in Ukrainian).

Kosenko, M.V., Malik, O.H. (2001). Veterynarni fitopreparaty: dovidnyk. [Veterinary herbal, directory]. Lviv: Spolom (in Ukrainian).

Chumachenko, V.E., Vysotsyy, A.M., Serduk, N.A., Chumachenko, V.V. (1990). Opredelenie estestvennoy resistentnosti i obmena veschestv u selskochozyaystvennykh zyvotnykh. [Determination of native resistance and metabolism in agricaltural animals] K.: Urozhay (in Russian).

Rokytskyy, P.F. (1973) Byolohycheskaya statistika. [Biological Statistics] - Minsk: Vyshejshaja shkola. (in Russian).

Стаття надійшла до редакції 1.10.2016 